УДК 347.77:004.73(477)

\author{
Є. О. Харитонов, О. І. Харитонова
}

\title{
ДЕЯКІ ПРОБЛЕМИ ХАРАКТЕРИСТИКИ КАТЕГОРІЇ «ІНТЕРНЕТ-ПРАВОВІДНОСИНИ»
}

Постановка проблеми. На початку третього тисячоліття інформаційні технології, пов'язані зі Всесвітньою Мережею (Інтернет), продовжували стрімко розвиватися, результатом чого стало те, що за перше десятиліття XXI ст. кількість користувачів у Мережі зросла з 350 мільйонів до більше ніж двох мільярдів [1, с. 10]. Сформувалося покоління «I-Gen» (Internet Generation), для якого визначальним $є$ право вільного доступу до кожного інтелектуального продукту в Мережі. Значення інформаційно-комунікаційних технологій у бутті суспільства зумовило прийняття країнами «Великої вісімки» в Окінаві у 2000 р. Хартії глобального інформаційного суспільства (Окінавська хартія). В Україні головні напрями державної політики в галузі інформатизації визначені Указом Президента України «Про заходи щодо розвитку національної складової глобальної інформаційної мережі Інтернет та забезпечення широкого доступу до цієї мережі в Україні», котрим, зокрема, передбачається вдосконалення правового регулювання діяльності суб'єктів інформаційних відносин, виробництва, використання, поширення та зберігання електронної інформаційної продукції, захисту прав на інтелектуальну власність, посилення відповідальності за порушення встановленого порядку доступу до електронних інформаційних ресурсів усіх форм власності, за навмисне поширення комп'ютерних вірусів тощо.

Разом із тим не можна не зважати на думку, що «комп'ютеризація суспільства» загрожує настанням транснаціональної антиутопії, бо Інтернет з інструмента звільнення може перетворитися в небезпечний засіб тотального контролю. При цьому виникає колізія інтересів держави й особи, яка має бути вирішена так, аби гарантувати свободу волевиявлення там, де це можливо, і стримувати наступ антиутопії там, де перше неможливе [2].

Отже, існує низка серйозних проблем, пов'язаних із поширенням у суспільстві інформаційно-комунікаційних технологій, принаймні частина яких може бути вирішена правовими засобами шляхом упорядкування відносин, що складаються в цій сфері, та узгодження інтересів їх суб'єктів.

У зв'язку з цим актуальною є класифікація правовідносин, які виникають у сфері Інтернет, що може дати змогу в майбутньому більш точно з'ясувати їх сутність. 
Мета статті - дослідити категорії «Інтернет-відносини» й «Інтернет-правовідносини», їх особливості та співвідношення між ними.

Виклад основного матеріалу дослідження. Приступаючи до розгляду відповідної проблеми, варто звернути увагу на те, що в контексті дослідження предмета правового регулювання в IT-сфері використовуються терміни «інформаційні відносини», «інформаційно-комунікаційні відносини», «інтернет-відносини», «ТТ-відносини» тощо [3, с. 396].

Найбільш популярним із них як об’єкт дослідження $€$ «нттернет-відносини», що визначають як частину відносин у віртуальному просторі, учасниками яких є носії суб'єктивних прав та обов'язків у мережі Інтернет [4, с. 8]. Специфіку цих відносин убачають у невизначеності місцезнаходження сторін; складнощах ідентифікації учасників відносин у мережі Iнтернет; залежності відносин між учасниками мережі Інтернет від відносин з інформаційними провайдерами; електронному характері документообігу в мережі [5, с. 72]; невизначеності юридичного статусу мережі Інтернет; існуванні віртуальних організацій тощо[6, с. 42-55].

Аналізуючи науковий доробок у цій галузі, передусім необхідно зробити деякі уточнення термінологічного характеру, зокрема стосовно вживання виразу «мережа Інтернет» (котрий іноді використовувався й у наших працях). Неточність полягає в тому, що термін «Інтернет», власне, вже означає «міжнародна мережа» (від англ. International Network) [7], «міжмережа» [8]. Тому виходить, що «мережа Інтернет» - це щось на кшталт «мережа міжнародної мережі». Очевидно, цілком достатньо позначення «Інтернет» або ж «Мережа».

Так само некоректним є використання терміна «Інтернет-відносини» [6, с. 198]. Натомість має йтися про «відносини в Інтернет», оскільки відносини, що складаються в Мережі, існують одночасно з реальними стосунками, віртуально відображаючи останні та збігаючись із ними за змістом. Віртуальні відносини можна класифікувати за предметним критерієм так само, як і відносини реальні. Отже, у цифровому середовищі після врегулювання їх юридичними нормами виникають правові відносини різної галузевої належності: цивільні, адміністративні, фінансові тощо. Крім того, за їх межами залишаються правовідносини, що виникають у разі порушення прав та обов'язків суб'єктами, які діють у Мережі, - правовідносини цивільної, адміністративної, карної тощо відповідальності. (Утім із урахуванням зробленого застереження з міркувань зручності викладу терміни «Інтернет-відносини» й «Інтернет-правовідносини» вживаються й у цій статті, але в лапках, аби підкреслити іх умовність.)

Відсутність предметної цілісності відносин в Інтернет дає підстави для висновку про необгрунтованість визнання існування окремих категорій «Інтернет-право», «Інтернет-правовідносини», «Інтернет-відносини», а тим більше вести мову про «Інтернет-право» як про «змішаний» або «комплексний» інститут [9, с. 42-44], галузь чи підгалузь права або законодавства.

Натомість має йтися про виникнення в цій сфері регулятивних правовідносин різної галузевої належності: цивільно-правових, адміністратив- 
но-правових тощо. Що стосується понять «Інтернет-відносини», «Інтернет-правовідносини», «Інтернет-право», «ТТ-право», то вони, звісно, можуть використовуватися в юридичному побуті, але лише як правові концепти, тобто як вербально виражені сукупності уявлень, понять, знань, асоціацій, емоцій, що виникають у зв'язку з використанням відповідних термінів, супроводжують і характеризують їх [10, с. 316].

У кожному разі «Інтернет-відносини» (якщо вже з прагматичних міркувань для забезпечення стислості викладу використовувати такий термін для позначення сукупності відносин, що складаються в Інтернеті) є лише частиною більш загальної категорії «ТТ-відносини», під якими в першому наближенні можна розуміти всю сукупність суспільних відносин, що виникають у процесі (в результаті) створення й використання інформаційних технологій. Отже, «ІТ-відносини» є загальною категорією, що включає також і відносини, які складаються в Інтернеті.

При цьому «ІТ-відносини» включають також інші «інформаційні», «інформаційно-комунікаційні» відносини, але можуть не бути власне «інформаційними» в точному значенні цього слова, оскільки охоплюють широке коло різноманітних відносин, які регулюються нормами цивільного, господарського, адміністративного законодавства. Зокрема, до сфери цивільно-правового регулювання належать відносини надання послуг програмного забезпечення або його розробки; правового захисту web-сторінок і контенту; юридичної допомоги у відкритті IT-бізнесу; юридичного аудиту IT-компаній; юридичного обслуговування фрилансерів; оформлення та захисту авторських прав і торгової марки в Інтернеті; оформлення договорів купівлі-продажу сайту, домену, бренду тощо; правового забезпечення діяльності Інтернет-магазинів; створення й реєстрації юридичних осіб у цій галузі; ліцензійних угод; захисту прав інтелектуальної власності; захисту інформації тощо [11, с. 136].

На такому підгрунті можемо визначити «Інтернет-відносини» як складову частину концепту «ІТ-відносини», сукупність суспільних відносин, що складаються в специфічному середовищі (Інтернет, Мережа, цифрове середовище), будучи одночасно «віртуальним феноменом» і виявляючись у бутті суспільства як реальні суспільні відносини. Завдяки останній особливості (своїй подвійній природі) вони можуть бути предметом правового регулювання і ставати правовідносинами.

Тут варто згадати досить поширену позицію, прихильники якої пропонують ігнорувати різницю між «Інтернет-відносинами» та «Інтернет-правовідносинами», аргументуючи виправданість такого підходу доцільністю зарахування «Інтернет-відносин» до нового типу суспільних відносин, що виникають, змінюються і припиняються в кіберпросторі. При цьому зазначається, що це не правові в чистому вигляді й не фактичні відносини, а спеціальні зв'язки особливої правової, інформаційної та технічної природи $[12$, с. $272 ; 13$, с. $5-11 ; 14$, с. $23-28 ; 15$, с. 272$]$.

Зазначене свідчить про важливість установлення співвідношення категорій «ТТ-правовідносини» та «правовідносини», а також з'ясування осо- 
бливостей правовідносин, що виникають в інформаційно-комунікаційній cферi.

Розмаїття відносин, котрі складаються в Інтернеті, створює на практиці істотні незручності під час пошуку актів законодавства, що стосуються різних видів таких відносин; пошуку й систематизації норм права, матеріалів практики; субсидіарного застосування норм законодавства, застосування аналогії закону тощо. Отже, маємо визначити орієнтири для встановлення кола правовідносин, котрі можна вважати органічно властивими Мережі.

Методологічною основою дослідження цього питання, на нашу думку, має бути розрізнення концепту «Інтернет-право» (який використовується тут нами 3 певними застереженнями, зробленими вище) у широкому та вузькому значеннях.

Під «Інтернет-правом» у широкому значенні ми пропонуємо розуміти всю сукупність норм і правил, що стосуються інформаційно-комунікаційної активності в Інтернет. Його структура виглядає як досить інтегрована система багаторівневого порядку, що включає приватноправові та публічно-правові елементи. Необхідність урахування приватноправового та публічно-правового забарвлення IT-відносин має враховуватися, щоб визначити пріоритетність інтересів (приватні чи публічні), а відтак мати можливість установити мотивацію застосування певних методів правого регулювання. Разом із тим публічно-правові за своєю сутністю відносини можуть складатися й у галузі цивільного права. Наприклад, такими є відносини цивільної відповідальності за шкоду, завдану цивільним правопорушенням в Інтернеті, наслідки чого визначаються безпосередньо нормами законодавства й не можуть бути змінені або припинені за домовленістю.

Натомість під «Інтернет-правом» у вузькому значенні, на нашу думку, варто розуміти лише ті правові норми, що стосуються правомірної (у тому числі «юридично-байдужої») діяльності в Мережі, передусім регулятивні норми (переважно цивільно-правові), що забезпечують функціонування «нтернет-відносин».

Оскільки в публікаціях, присвячених питанням правового регулювання в Інтернеті, зустрічається твердження, що правові норми, які регулюють діяльність у Мережі, мають змішаний приватно-публічний характер [16, с. 172-182], доцільно розглянути цю тезу з погляду коректності іiі застосування щодо «Інтернет-правовідносин».

Відзначивши методологічну хибність самого виразу «правові норми ... мають змішаний приватно-публічний характер» (очевидно, усе ж таки мається на увазі змішаний приватно-публічний характер актів законодавства), розглянемо, як поєднуються приватноправовий і публічно-правовий підходи під час регулювання «Інтернет-відносин».

Передусім це має значення для встановлення первинності та вторинності таких категорій, як «Інтернет-відносини» й «Інтернет-правовідносини».

У тому випадку, коли йдеться про правомірну діяльність приватних осіб (не держави та іiі фігурантів) в Інтернеті, суспільні відносини є первинними щодо правовідносин, оскільки можуть виникати на підставі угоди 
сторін, унаслідок фактичних дій суб’єктів тощо. На існування цих відносин не впливає наявність або відсутність актів законодавства, бо права й обов'язки сторін таких цивільних відносин мають основою норми природного права, що забезпечує їх включення у правову сферу. Отже, «Нтернет-відносини» тут є первинними щодо «Інтернет-правовідносин», зумовлюючи характер і зміст останніх.

Однак, коли йдеться про суспільні відносини, пов'язані з публічними інтересами (наприклад, забезпечення інформаційної безпеки), відповідні «Інтернет-відносини» потрапляють у сферу дії публічного права. Оскільки публічне право є продовженням публічної влади й виявом останньої, то воно, як правило, є чинником установлення не тільки правовідносин, а й самих публічних відносин, визначаючи, коли, чому та для чого вони формуються. При цьому відповідні «Інтернет-відносини» виникають і здійснюються згідно з приписами правової норми, і саме в цьому виявляється реалізація останньої, перетворення ії в акт конкретної поведінки. Під таким кутом зору «Інтернет-правовідносини» можуть розглядатися як результат діï норми права, що за формою є індивідуально визначеним зв'язком управомочених і зобов'язаних осіб, а за змістом - взаємодією цих осіб, які реалізують свої права та виконують обов'язки. (Аби не перевантажувати статтю в цій частині посиланнями, обмежимось згадкою про наші публікаціï, де ці питання розглядалися раніше [17, с. 11-18].)

Отже, для визначення співвідношення категорій «ннтернет-відносини» та «Інтернет-правовідносини», зокрема встановлення їх первинності одне щодо одного, вирішальним критерієм є сфера права, до якої вони належать у конкретному випадку. Звідси випливає, що відповідно до розмежування сфери приватного й публічного права варто розрізняти приватні й публічні «Інтернет-правовідносини».

Урахування приватних і публічних засад дає також можливість характеристики сутності правового регулювання «Інтернет-відносин».

Розглядаючи це питання, виходимо з того, що «правове регулювання» визначається як один із основних засобів державного впливу на суспільні відносини з метою їх упорядкування в інтересах людини, суспільства й держави. Воно є різновидом соціального регулювання, а його предметом $€$ правові, політичні, економічні й інші суспільні відносини, впорядкування яких неможливе без використання норм права. Елементами механізму правового регулювання є: 1) норми права, зафіксовані в законах та інших правових актах, якими визначається модель можливої й необхідної поведінки суб'єктів суспільних відносин; 2) юридичні факти; 3) власне правовідносини; 4) акти реалізації прав та обов'язків суб'єктів суспільних відносин, тобто дії цих суб'єктів у межах приписів відповідних правових норм; 5) правові санкції щодо порушників норм права [18, с. 40-41].

Завдання соціального регулювання вирішуються шляхом узгодження інтересів публічних (державних), колективних і приватних. У випадках неефективності соціального регулювання суперечності між цими інтересами можуть поглиблюватись (як це, наприклад, має місце у випадку колізій 
між правами авторів і правами вільного доступу до інформації користувачів Інтернет тощо).

Об’єктами регулятивних «Інтернет-правовідносин» є поведінка людей, а також конкретні блага, стосовно яких складаються відносини між людьми: 1) речі; 2) дії (послуги); 3) результат дій (результат робіт); 4) результати інтелектуальної, творчої діяльності й інші об'єкти права інтелектуальної власності; 5) інформація. При цьому види регулятивних «нттернет-правовідносин», які виникають стосовно інформації, залежать від типу останньої. Так, фізичні та юридичні особи, які володіють інформацією професійного, ділового, виробничого, банківського, комерційного й іншого характеру, одержаною за власні кошти, або яка є предметом їх професійного, ділового, виробничого, банківського, комерційного й іншого інтересу, як правило, самостійно визначають режим доступу до неї, включаючи належність iii до категорії конфіденційної, і встановлюють систему захисту. Тобто тут мають місце регулятивні цивільні правовідносини, у яких права й обов'язки їх учасників щодо об’єкта (інформації) визначаються в диспозитивному порядку. Інші правила діють щодо інформації, яка відповідно до закону $є$ державною, комерційною, службовою, професійною таємницею. Так, державна та службова таємниці взагалі вилучені з кола об'єктів цивільних відносин і регулюються нормами публічно-правового характеру, котрі найчастіше належать до сфери адміністративного права, завдяки чому тут виникають адміністративні правовідносини.

Оскільки «регулювання» $€$ концептом, що включає як публічні, так i приватні феномени, які забезпечують функціонування соціальних систем, упорядкування суспільних відносин може здійснюватися двома шляхами: 1) регулюванням спеціальним суб'єктом; 2) саморегулюванням. Якщо в першому випадку регулювання здійснюється спеціально уповноваженим суб'єктом (держава, органи місцевого самоврядування тощо), що має можливість владного вПливу на поведінку інших осіб, то в другому - регулювання відносин учасників відносин здійснюється ними самотужки на основі домовленості.

Але через те, що регулятивні «Інтернет-відносини» можуть належати до сфери як приватного, так і публічного права, виникає необхідність розмежування регулятивних цивільних правовідносин і регулятивних адміністративно-правових відносин, із якими пов'язують виконання управлінських функцій.

Порівнюючи два згадані види правовідносин, передусім варто згадати таку названу вище рису, властиву публічним правовідносинам, а саме вони $€$ «первинними» стосовно суспільних відносин. Правовідносини в галузі публічного права загалом, а отже, і в галузі адміністративного права виникають, змінюються та припиняються тільки на підставі правових норм, що містяться в актах законодавства, котрі безпосередньо породжують правовідносини й реалізуються через них. Між цими явищами (нормою, встановленою актом адміністративного законодавства, та адміністративно-правовими відносинами) існує причинний зв'язок. Що стосується 
сфери приватного права, то в ній суспільні відносини можуть опосередковуватися й іншими (неюридичними) нормами. Тому тут можлива ситуація, коли цивільні «Інтернет-відносини» сторін узагалі можуть не потребувати правового втручання.

Висновки. Підсумовуючи викладене, можна резюмувати, що правовідносин, які виникають в Інтернет, передусім мають бути поділені на: 1) відносини приватного та публічного права, 2) відносини регулятивні й охоронні. При цьому визначальним є загальний поділ правовідносин на ті, що виникають у галузі приватного права, і ті, що виникають у галузі публічного права. Залежності від того, є відносини публічно-правовими чи приватноправовими, визначається їх зв'язок із певною галуззю права, а відтак те, якими є їх властивості. Крім того, беремо до уваги ту обставину, що ««Інтернет-правовідносини» за своєю сутністю є регулятивними правовідносинами, типовими переважно для цивільного права.

Зазначені положення можуть слугувати підгрунтям аналізу сутності правовідносин у сфері Інтернет і їх співвідношення з концептами «ІТ-відносини», «ІТ-правовідносини» тощо, знімаючи, до речі, питання про доцільність характеристики відносин у цій сфері як «неправових у чистому вигляді» й не «фактичних» відносин.

\section{Література}

1. Шмідт Е. Новий цифровий світ / Е. Шмідт, Дж. Коен ; пер. з англ. - Львів : Літопис, 2015. -368 с

2. Ассанж Дж. Про майбутнє Інтернету / Дж. Ассанж [Електронний ресурс]. - Режим доступу : http://interviews.com.ua/c/612-assange-internet/.

3. IТ-право: проблеми і перспективи розвитку в Україні : збірник матеріалів науково-практичної конференції. - Львів : НУ «Львівська політехніка», 2016. - 396 с.

4. Рассолов И.М. Право и Интернет: теоретические проблемы : автореф. дисс. ... докт. юрид. наук / И.М. Рассолов. - М., 2008. - С. 8.

5. Дмитрик Н.А. Осуществление субъективных гражданских прав с использованием сети Интернет / Н.А. Дмитрик. - М., 2006. - 200 с.

6. Глушков А.В. Проблемы правового регулирования Интернет-отношений : дисс. ... канд. юрид. наук / А.В. Глушков. - СПб., 2007. - С. 198.

7. Див. [Електронний ресурс]. - Режим доступу : htth://nataliamyk.blogspot.spot. $\mathrm{com} / 2015 / 01 / 3 . h t m l$.

8. Див. [Електронний ресурс]. - Режим доступу : http:/ / uk/wikipedia.org/wiki.

9. Рассолов И.М. Право и Интернет: теоретические проблемы / И.М. Рассолов. - 2-е изд., доп. - М. : Норма, 2009. - 383 с.

10. IT-право: поняття та сутність : [монографія] / за ред. О.І. Харитонової, Є.О. Харитонова. - Одеса : Фенікс, 2017. - 384 с.

11. Бачинський Т. Основи IT-права / Т. Бачинський. - Львів : Апріорі, 2016. - 136 с.

12. Литвинов Є.П. Правовідносини в інтернет-праві / Є.П. Литвинов / / Часопис Київського університету права. - 2013. - № 3. - С.145-149.

13. Єфремова К.В. До перспектив правового регулювання інтернет-правовідносин: господарсько-правовий аспект / К.В. Єфремова / / Право та інноваційне суспільство. - 2014. № 1. - C. 5-11.

14. Барабаш О.О. Загальна характеристика інтернет-правовідносин / О.О. Єфремова // IT-право: проблеми і перспективи розвитку в Україні : збірник матеріалів науково-практичної конференції. - Львів : НУ «Львівська політехніка», 2016. - С. 23-28.

15. Незнамов А.В. Особенности компетенции по рассмотрению Интернет-споров / А.В. Незнамов ; науч. ред. В.В. Ярков. - М. : Инфотропик Медиа, 2011. - 272 с. 
16. Енан Р.Є. Правове регулювання відносин у мережі Інтернет / Р.Є. Енан / / IT-право: проблеми і перспективи розвитку в Україні : збірник матеріалів науково-практичної конференції. - Львів : НУ «Львівська політехніка», 2016. - С. 172-182.

17. Харитонов Є.О. Цивільні правовідносини / Є.О. Харитонов, О.І. Харитонова. - Фенікс, 2011. -458 c.

18. Юридична енциклопедія : в 6 т. / редкол.: Ю.С. Шемшученко (голова редкол.) та ін. К. : Укр. енцикл., 1998-2004. - Т. 5. - 2003. - 672 с.

\section{Ано т а ці я}

Харитонов Є. О., Харитонова О. I. Деякі проблеми характеристики категорії «Інтернет-правовідносини». - Стаття.

У статті досліджуються категорії «Інтернет-відносини» й «Інтернет-правовідносини», їх особливості та співвідношення між ними. Доводиться, що під час характеристики «нтернет-правовідносин» має враховуватись поділ правовідносини на відносини приватного й публічного права, регулятивні та охоронні тощо. У процесі аналізу концепту «Інтернет-правовідносини» передусім мають бути визначені ї властивості з урахуванням того, що вони належать до сфери приватного права. Крім того, необхідно враховувати, що «Інтернет-правовідносини» за своєю сутністю є регулятивними (переважно цивільними) правовідносинами.

Ключові слова: Інтернет-відносини, ІТ-правовідносини, мережа Інтернет.

\section{Ан нот а ци я}

Харитонов $E$. A., Харитонова $E$. И. Некоторые проблемы характеристики категории «Интернет-правоотношения». - Статья.

В статье исследуются категории «Интернет-отношения» и «Интернет-правоотношения», их особенности и соотношение между ними. Доказывается, что при характеристике «Интернет-правоотношений» должно учитываться разделение правоотношения на отношения частного и публичного права, регулятивные и охранительные и тому подобное. При анализе концепта «Интернет-правоотношения» прежде всего должны быть определены их свойства с учетом того, что они относятся к сфере частного права. Кроме того, необходимо учитывать, что «Интернет-правоотношения» по своей сути являются регулятивными (в основном гражданскими) правоотношениями.

Ключевые слова: Интернет-отношения, ИТ-правоотношения, сеть Интернет.

\section{S u m m a r y}

Kharytonov Ye. O., Kharytonova O. I. Some problems characteristic category "Internet relationship". - Article.

The article investigates the category "Internet relationship" and "Internet relationship", their characteristics and relationships between them. Proved that characterize the "Internet relationship" should be taken into account in the legal division: the relationship of private and public law, regulation and security and so on. In analyzing the concept of "Internet relationship" primarily be determined on the basis of their properties that they belong to the sphere of private law. Also, be aware that the "Internet relationship" is essentially regulatory (mostly civilian) legal relationship.

Key words: Internet relationships, legal IT, Internet. 